\title{
Chiasma frequencies and distributions in gomphocerine grasshoppers: a comparative study between sexes
}

\section{I. Cano and \\ J. L. Santos}

Departamento de Genética, Facultad de Biología, Universidad Complutense, 28040 Madrid.

Frequency and position of chiasmata at metaphase I were studied in spermatocytes and oocytes from six species of gomphocerine grasshoppers $\left(2 \mathrm{n} \sigma^{\star}=16+\mathrm{XO} ; 2 \mathrm{n} q=16+\mathrm{XX}\right)$, namely: Omocestus panteli, Euchorthippus pulvinatus, Euchorthippus chopardi, Chorthippus vagans, Chorthippus parallelus and Chorthippus jucundus. In the latter species mean cell chiasma frequency was similar in both sexes. However in the remainder chiasma frequencies were higher in males than in females. Within each species different bivalents are responsible for the sex chiasma differences that can be interpreted as a relatively simple bivalent based system of chiasma control. Chiasmata were non-localised in both sexes of all species analysed but females showed altered chiasma distributions compared with males, with fewer proximal chiasmata and more interstitial and distal chiasmata.

\section{INTRODUCTION}

Most of the information available on meiotic recombination at the cytological level has been obtained from observations of male meiosis because the analysis of female meiosis has been hampered by technical and operative difficulties, namely, it is difficult to identify female meiocytes at the correct cytological stage for chiasma observations and the number of suitable cells for analysis is usually low. Nevertheless, there are a limited number of reports where chiasma frequencies in both sexes of several plant and animals species have been established. In most of them, females have a higher chiasma frequency than males as for example in Dendrocoelum lacteum (Pastor and Callan, 1952); Lilium and Fritillaria (Fogwill, 1958); Triturus helveticus (Watson and Callan, 1963); and Tulbaghia (Vosa, 1972). However, there are cases in which both sexes present similar chiasma frequencies (Bennett et al., 1973, barley; Davies and Jones, 1974, rye; Speed, 1977 , mouse) and others where males display the higher recombination frequencies (Watson and Callan, 1963, Triturus cristatus; Gohil and Kahul, 1980, four species of Allium; and Bennett et al., 1986, the marsupial Sminthopsis crassicaudata).

In Orthoptera, despite the technique developed by Perry and Jones (1974) and subsequently modified by Henriques-Gil et al. (1986) that allows the routine production of well spread first metaphase oocytes, the number of different species examined is relatively low (see Cano et al., 1987 for references) since the major interest has been especially focused to those species in which males show extreme localisation of chiasmata: Stethophyma grossum (Perry and Jones, 1974), Parapleurus alliaceus and Chrysochraon dispar (Fletcher and Hewitt, 1980). In the present paper, we extended this type of study based on the comparisons of chiasma frequencies and distributions in both sexes to six species of gomphocerine grasshoppers that show a uniform karyotype: 17 chromosomes $(16+\mathrm{X})$ in the males and 18 chromosomes $(16+\mathrm{XX})$ in the females and non-restricted chiasma localisation in the heterogametic sex.

\section{MATERIAL AND METHODS}

The six species of gomphocerine grasshoppers studied here were the following: Omocestus panteli (O. p.), Chorthippus vagans (Ch. v.), Chorthippus parallelus (Ch. p), Chorthippus jucundus (Ch. j.), Euchorthippus pulvinatus (E. p.) and Euchorthippus chopardi (E. ch.). In all of them 12 males and 12 females were cytologically analysed. Testes were removed from mature adult males, fixed in $3: 1$ 
ethanol: acetic acid and stored in fix at $4^{\circ} \mathrm{C}$ prior to making orcein stained squash preparations. Females were maintained in cages in laboratory conditions until required. Squash preparations of oocyte first metaphase were made using the method of Perry and Jones (1974) as modified by Henriques-Gil et al. (1986). To ensure comparability, all chiasma scoring was carried out on first metaphase stages in both oocytes and spermatocytes under the assumption that chiasma terminalisation does not exist in these species (Santos et al., 1989). Ten spermatocytes were scored per male insect and five oocytes per female. In adddition to chiasma frequency per bivalent, the position of each chiasma was recorded and for this purpose chiasmata were classified arbitrarily as proximal, interstitial or distal with respect to the centromere. The first class include 25 per cent of the total chromosome arm or bivalent length whereas the second and the third ones correspond to 50 and 25 per cent respectively.

\section{RESULTS}

\section{The karyotype}

The six species analysed here have similar karyotypes consisting of 17 chromosomes in the males $(16+\mathrm{X})$ and 18 in the females $(16+\mathrm{XX})$. There are three long pairs of autosomes (L1-L3) with submetacentric organisation and five medium to small sized autosomes (M4-S8) plus the X chromosome with telo- or subtelocentric organisation. The $\mathrm{X}$ chromosome is the longest of the teloor subtelocentric chromosomes, but it is sufficiently close in size to the M4 autosome pair to prevent consistent identification of the $\mathrm{X}$ bivalent in oocytes. Difficulties in the identification of L1 and L2, M5 and M6 and M7 and S8 bivalents were also found in spermatocytes and occytes. According to these observations we have compared the frequency and distribution of chiasmata in both sexes not only at the level of the whole complement but also considering five individualised bivalent groups: L1-L2, L3, X-M4, M5-M6 and M7-S8.

\section{Mean chiasma frequencies}

The sex system of these grasshoppers is XX females and XO males. Thus the females have an extra bivalent formed by the sex chromosomes while the males have an X univalent in spermatocytes. As it has been mentioned above the $\mathrm{X}$ bivalent cannot be distinguished from the M4 pair due to similarities in morphology and size, therefore for a direct comparison of male and female chiasma frequencies both bivalents have been excluded. According with this, table 1 gives the mean chiasma frequencies per each bivalent group and per cell of male and female grasshoppers from the six species analysed. It is apparent from this table that with the exception of $C h$. jucundus where males and females display similar mean cell chiasma frequencies the remainder show female mean cell chiasma frequencies significantly lower than the corresponding male values. In all species M7 and S8 pairs invariably form one chiasma in both sexes.

\section{CHIASMA DISTRIBUTION}

In order to compare chiasma distribution between sexes bivalent groups with different numbers of chiasmata have been considered separately. The data are presented in table 2 and the most remarkable feature that emerges from them is that females show proportionally an excess of distal chiasmata in comparison with males, although chiasma distribution patterns both in males and females vary according to the bivalent class. Selected metaphase I spermatocytes and oocytes of some of the species analysed here are shown in figs 1-8.

Differences in chiasma distributions between species can also be observed, expecially in monochiasmate bivalents. Thus the single chiasma is preferentially located in an interstitial region in $C h$. jucundus and Ch. parallelus whereas it has a tendency to be distally located in E. chopardi and $O$. panteli. E. pulvinatus represents an intermediate situation since it is usually distal in M7 and S8 pairs while it is located in interstitial regions in $\mathrm{X}$ and M4 pairs.

\section{DISCUSSION}

Haldane (1922) suggested that in species where recombination differences exist between sexes it is the heterogametic sex in which crossing over is lowered in frequency or is absent. An extreme illustration of this hypothesis is the almost universal restriction of achiasmate meiosis to the heterogametic sex in several invertebrate species like Drosophila melanogaster and Bombyx mori. To date, this suggestion appears to be untenable not only in eutherian mammals (Dunn and Bennett, 1967) but in marsupials (Bennett et al., 1986), urodele amphibians (Callan and Perry, 1977) and grasshoppers too. 
Table 1 Mean chiasma frequencies per bivalent group and per cell of male and female grasshoppers from the six species analysed. Comparisons of chiasma frequencies between sexes were carried out by means of $t$ tests

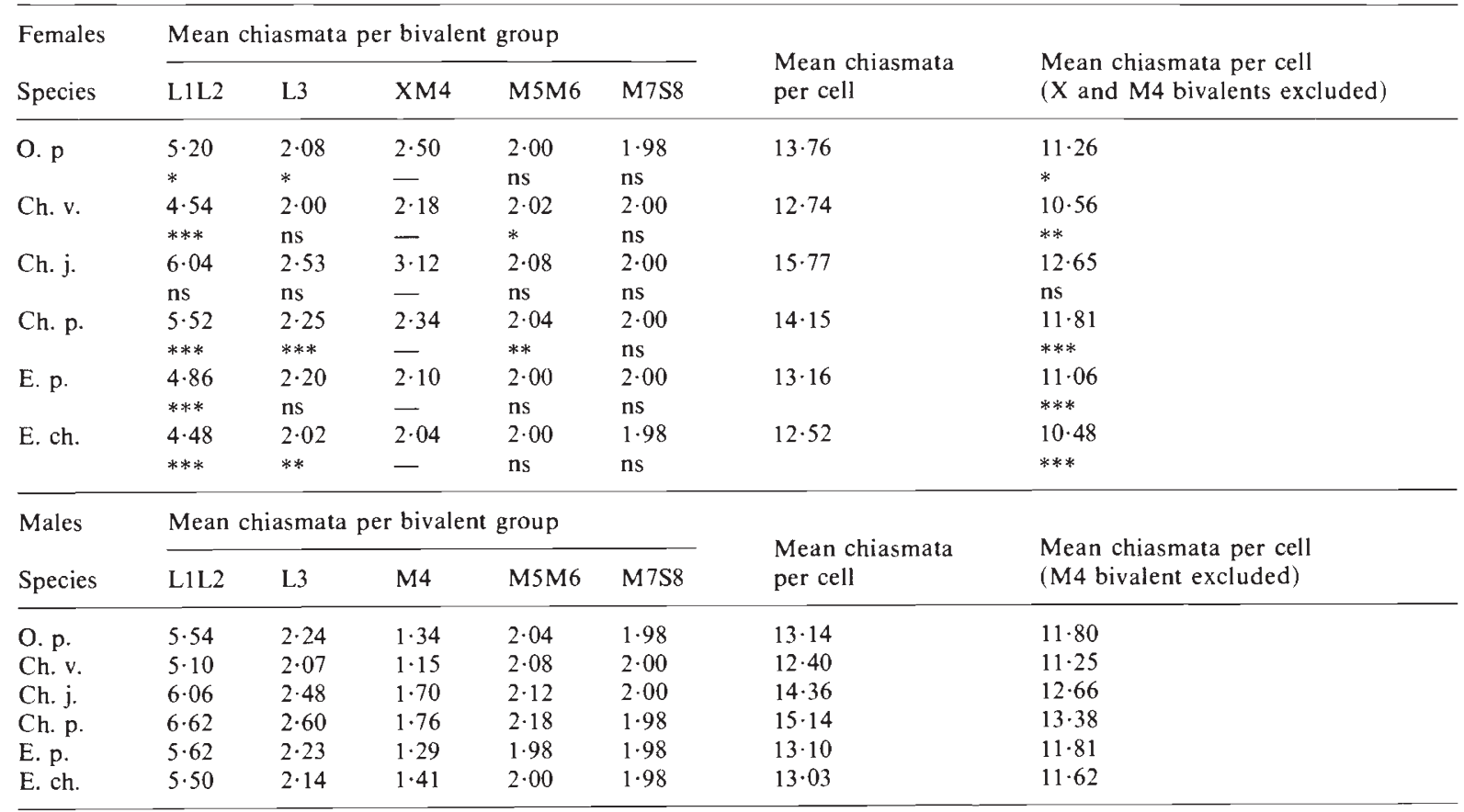

$*=0.01<P<0.05$.

$* *=0.005<P<0 \cdot 01$.

$* * *=P<0.005$.

Table 2 The distribution of chiasmata (Xta) among proximal (P), interstitial (I) and distal (D) bivalent segments for males and females from the six species analysed. The data are given separately for each different bivalent group

\begin{tabular}{|c|c|c|c|c|c|c|c|}
\hline \multirow[b]{2}{*}{ Species } & \multirow[b]{2}{*}{ Type of bivalent } & \multicolumn{3}{|c|}{ Females } & \multicolumn{3}{|c|}{ Males } \\
\hline & & $P$ & $I$ & $D$ & $P$ & $I$ & $D$ \\
\hline \multirow[t]{10}{*}{ O. p. } & L1L2 (2 Xta) & - & 26 & 70 & - & 46 & 84 \\
\hline & L1L2 (3 Xta) & - & 94 & 119 & 2 & 237 & 256 \\
\hline & L1L2 (4 Xta) & - & 2 & 2 & 5 & 20 & 15 \\
\hline & L3 (2 Xta) & - & 27 & 83 & 1 & 48 & 133 \\
\hline & L3 (3Xta) & - & 6 & 9 & - & 35 & 52 \\
\hline & $\mathrm{M} 4 \mathrm{X} \quad(1 \mathrm{Xa})$ & - & 39 & 51 & 17 & 28 & 34 \\
\hline & M4X (2 Xta) & 2 & 28 & 30 & 26 & 15 & 41 \\
\hline & M5M6 (1 Xa) & 7 & 30 & 83 & 27 & 69 & 139 \\
\hline & M5M6 (2 Xta) & 一 & - & - & 5 & 一 & 5 \\
\hline & M7S8 (1 Xa) & 1 & 8 & 110 & 2 & 68 & 169 \\
\hline \multirow[t]{12}{*}{ Ch. v. } & L1L2 (1 Xa) & - & 1 & 2 & - & 2 & 1 \\
\hline & L1L2 (2 Xta) & - & 37 & 133 & - & 95 & 115 \\
\hline & L1L2 (3 Xta) & - & 35 & 49 & 2 & 183 & 205 \\
\hline & L1L2 (4 Xta) & - & 12 & 4 & - & 4 & 4 \\
\hline & $\mathrm{L} 3 \quad(1 \mathrm{Xa})$ & - & 1 & 1 & - & 2 & - \\
\hline & $(2 \mathrm{Xta})$ & - & 13 & 100 & - & 51 & 163 \\
\hline & $\mathrm{L} 3 \quad(3 \mathrm{Xta})$ & - & 4 & 2 & 1 & 13 & 19 \\
\hline & M4X (1 Xa) & - & 38 & 71 & 5 & 36 & 61 \\
\hline & $\mathrm{M} 4 \mathrm{X} \quad(2 \mathrm{Xta})$ & - & 11 & 11 & 6 & 12 & 18 \\
\hline & M5M6 (1 Xa) & - & 8 & 111 & 一 & 49 & 82 \\
\hline & M5M6 (2 Xta) & - & 1 & 1 & 6 & 3 & 9 \\
\hline & M7S8 (1 Xa) & - & 1 & 119 & - & 12 & 228 \\
\hline
\end{tabular}


Table 2 continued

\begin{tabular}{|c|c|c|c|c|c|c|c|c|}
\hline \multirow{3}{*}{$\frac{\text { Species }}{\text { Ch. j. }}$} & \multirow{2}{*}{\multicolumn{2}{|c|}{ Type of bivalent }} & \multicolumn{3}{|c|}{ Females } & \multicolumn{3}{|c|}{ Males } \\
\hline & & & \multirow{2}{*}{$\frac{P}{-}$} & \multirow{2}{*}{$\begin{array}{l}I \\
9\end{array}$} & \multirow{2}{*}{$\frac{D}{11}$} & \multirow{2}{*}{$\frac{P}{-}$} & \multirow{2}{*}{$\begin{array}{l}I \\
20\end{array}$} & \multirow{2}{*}{$\frac{D}{6}$} \\
\hline & L1 L2 & $(2 \mathrm{Xta})$ & & & & & & \\
\hline & L1 L2 & $(3 \mathrm{Xta})$ & 2 & 176 & 122 & 一 & 372 & 249 \\
\hline & L1L2 & (4Xta) & 2 & 21 & 13 & - & 39 & 37 \\
\hline & L1L2 & $(5 \mathrm{Xta})$ & - & 3 & 2 & - & - & - \\
\hline & L3 & $(1 \mathrm{Xa})$ & - & 1 & - & - & - & - \\
\hline & L3 & $(2 \mathrm{Xta})$ & 1 & 30 & 19 & - & 88 & 36 \\
\hline & L3 & $(3 \mathrm{Xta})$ & 2 & 58 & 42 & - & 91 & 83 \\
\hline & $\mathrm{M} 4 \mathrm{X}$ & $(1 \mathrm{Xa})$ & - & 29 & 24 & 5 & 26 & 5 \\
\hline & $\mathrm{M} 4 \mathrm{X}$ & $(2 \mathrm{Xta})$ & 4 & 76 & 54 & 49 & 43 & 76 \\
\hline & M5M6 & $(1 \mathrm{Xa})$ & - & 65 & 50 & 11 & 117 & 97 \\
\hline & M5M 6 & $(2 \mathrm{Xta})$ & 1 & 4 & 5 & 14 & 1 & 15 \\
\hline & M7S8 & $(1 \mathrm{Xa})$ & 1 & 49 & 70 & 4 & 162 & 74 \\
\hline \multirow[t]{13}{*}{ Ch. p. } & L1L2 & $(2 \mathrm{Xta})$ & - & 34 & 24 & 一 & 17 & 1 \\
\hline & L1L2 & (3 Xta) & - & 172 & 98 & 3 & 331 & 134 \\
\hline & L1L2 & $(4 \mathrm{Xta})$ & - & 2 & 2 & 14 & 153 & 109 \\
\hline & L1L2 & $(5 \mathrm{Xta})$ & - & - & - & 5 & 13 & 12 \\
\hline & $\mathrm{L} 3$ & $(1 \mathrm{Xa})$ & - & 1 & - & - & - & - \\
\hline & L3 & $(2 \mathrm{Xta})$ & - & 56 & 30 & - & 74 & 12 \\
\hline & L3 & $(3 \mathrm{Xta})$ & - & 26 & 32 & 8 & 141 & 79 \\
\hline & L3 & (4Xta) & - & - & - & - & 2 & 2 \\
\hline & M4X & $(1 \mathrm{Xa})$ & 2 & 66 & 32 & 1 & 26 & 2 \\
\hline & M4X & (2Xta) & 1 & 20 & 19 & 60 & 51 & 71 \\
\hline & M5M & $6(1 \mathrm{Xa})$ & 1 & 76 & 41 & 16 & 135 & 68 \\
\hline & M5M & $5(2 \mathrm{Xta})$ & - & 2 & 2 & 15 & 10 & 17 \\
\hline & M7S8 & $(1 \mathrm{Xa})$ & - & 68 & 52 & 28 & 157 & 53 \\
\hline \multirow[t]{11}{*}{ E. p. } & L1 L2 & $(1 \mathrm{Xa})$ & - & - & - & - & 1 & - \\
\hline & L1L2 & (2Xta) & - & 49 & 87 & - & 67 & 31 \\
\hline & L1L2 & (3 Xta) & 3 & 71 & 82 & - & 357 & 210 \\
\hline & L1L2 & $(4 \mathrm{Xta})$ & - & - & - & - & 6 & 6 \\
\hline & L3 & $(1 \mathrm{Xa})$ & - & - & - & - & 1 & - \\
\hline & L3 & (2Xta) & - & 42 & 54 & - & 113 & 68 \\
\hline & L3 & (3Xta) & 1 & 10 & 25 & - & 47 & 37 \\
\hline & $\mathrm{M} 4 \mathrm{X}$ & (1 Xta) & - & 52 & 62 & 12 & 52 & 21 \\
\hline & $\mathrm{M} 4 \mathrm{X}$ & (2Xta) & - & 6 & 6 & 19 & 19 & 32 \\
\hline & M5M & $(1 \mathrm{Xa})$ & - & 41 & 79 & 23 & 90 & 126 \\
\hline & $\mathrm{M} 7 \mathrm{~S} 8$ & $(1 \mathrm{Xa})$ & - & 3 & 117 & 9 & 98 & 132 \\
\hline \multirow[t]{11}{*}{ E. ch. } & L1L2 & $(1 \mathrm{Xta})$ & - & - & - & - & 1 & - \\
\hline & L1 L2 & (2Xta) & - & 52 & 130 & - & 78 & 48 \\
\hline & L1 L2 & (3Xta) & 1 & 28 & 58 & 16 & 257 & 140 \\
\hline & L1L2 & $(4 \mathrm{Xta})$ & - & - & - & 4 & 6 & 10 \\
\hline & L3 & $(1 \mathrm{Xa})$ & - & - & - & - & 1 & 1 \\
\hline & L3 & $(2 \mathrm{Xta})$ & - & 14 & 102 & 1 & 110 & 87 \\
\hline & L3 & (3Xta) & - & 2 & 4 & 2 & 27 & 28 \\
\hline & M4X & $(1 \mathrm{Xa})$ & 1 & 18 & 100 & 4 & 41 & 31 \\
\hline & M4X & (2Xta) & - & 1 & 1 & 15 & 30 & 43 \\
\hline & M5M & $(1 \mathrm{Xa})$ & - & 8 & 112 & 1 & 55 & 184 \\
\hline & M7S8 & $(1 \mathrm{Xa})$ & - & - & 119 & 1 & 36 & 202 \\
\hline
\end{tabular}

In gomphocerine grasshoppers there are species in which females display lower mean cell chiasma frequencies than males: Myrmeleotettix maculatus (Hewitt, 1976) and those reported in this work. However Chrysochraon dispar (Fletcher and Hewitt, 1980) shows the reverse situation and in others no differences between sexes have been found: Chorthippus brunneus (Jones et al., 1975) and Ch. jucundus (this work). In other species with 23 chromosomes in the male and 24 in the female different results have also been reported, for instance in Chortoicetes terminifera (Fletcher and Hewitt, 1980), Eyprepocnemis plorans (Cano et al., 1987) and Heteracris littoralis (Cano and Santos, 1988) chiasma frequency was significantly lower in the homogametic sex, however the reverse situ- 


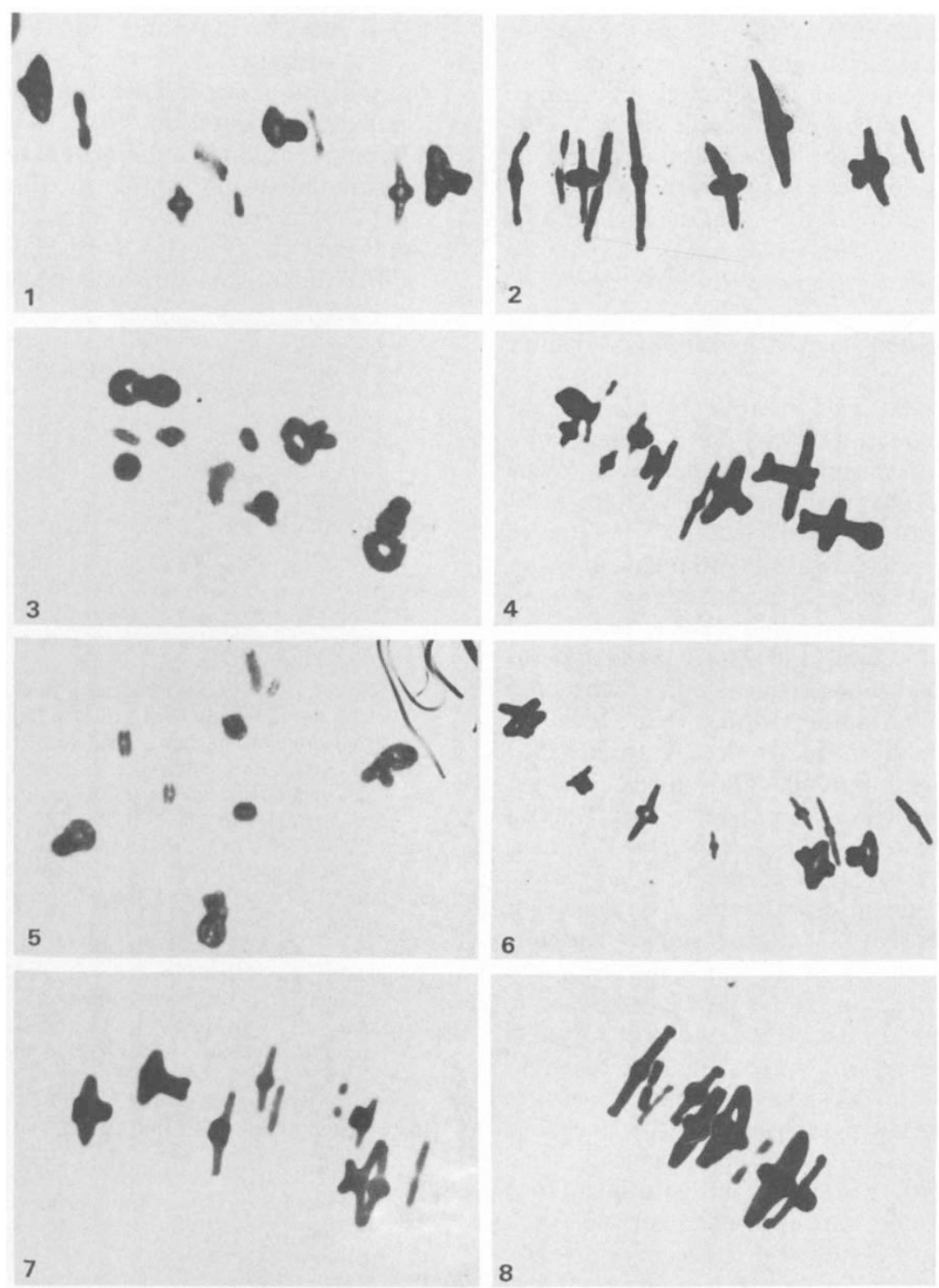

Figures 1-8 Meiotic first metaphases from oocytes (Figures 2, 4, 6, 7 and 8) and spermatocytes (Figures 1, 3 and 5). Euchorthippus pulvinatus (Figures 1-2). Chorthippus jucundus (Figures 3-4). Chorthippus parallelus (Figures 5-6). Omocestus panteli (Figure 7). Chorthippus vagans (Figure 8).

ation has also been described in Melanoplus femurrubrum (Church, 1974), Stethophyma grossum (Perry and Jones, 1974) and Parapleurus alliaceus (Fletcher and Hewitt, 1980).

The lack of a clear tendency in the patterns of differences in chiasma frequency between sexes, even between related species, makes it difficult to envisage the adaptive value, if any, of these changes in recombination. Moreover the situation can be more complex than that mentioned above since there are organisms like maize (see Rhoades, 1978) and mouse (Dunn and Bennett, 1967) with higher male crossing over in one chromosome region and higher female in another.

The male/female comparisons in different species lead to another question related with 
chiasma control. The results shown in table 1 indicate that different bivalents are responsible for the sex chiasma differences within each species. This fact can be interpreted as a relatively simple bivalent based system of chiasma control and would support the view that chiasma control in grasshoppers is bivalent-based, rather than cell based (Hewitt and John, 1965; Southern, 1967 and Jones et al., 1975). The existence of desynaptic mutants for specific chromosomes in Hypochoeris (Parker, 1975) and Crepis (Tease and Jones, 1976) has extended such a hypothesis to other organisms.

Sex differences in chiasma frequency are usually accompanied by variation in chiasma distributions, for instance in Triturus helveticus (Watson and Callan, 1963) male meiosis is characterised by distal localisation of chiasmata, while females display a great number of interstitial chiasmata in all bivalents. However in Triturus cristatus (Watson and Callan, 1963), Tulbaghia (Vosa, 1972) and Allium kachrooi (Gohil and Kaul, 1980) a trend toward a proximal chiasma localisation is observed in females. In grasshoppers with extreme localisation of chiasmata in males (see introduction) females have higher number of less localised chiasmata. In other species with non restricted chiasma localisation in both sexes like Chorthippus brunneus (Jones et al., 1975), Chortoicetes terminifera (Fletcher and Hewitt, 1980) and Eyprepocnemis plorans (Cano et al., 1987) females show a tendency to form more distal chiasmata than males. A similar situation takes place in the six species analysed in this work (table 2). However, there are doubts whether this represents a genuine difference in chiasma distribution. As it has been stated by Jones et al., (1975) meiotic figures in both sexes (see figs. 1-8) are quite different both in chromosome appearence and bivalent configuration, thus bivalents seem to be more extended in oocytes than in spermatocytes possibly due to the spindle being a larger structure in oocytes as compared to spermatocytes (White, 1973). This fact could affect chiasma distribution scores since it would lead to an apparent, though non real, increase of the distances from centromeres to chiasmata. On the other hand, it is well known that within certain species when the mean chiasma frequency is low the probability that chiasmata are distally located is high. This would be in agreement with data obtained from species analysed here. Therefore, we believe that in these species, at least in those in which females display lower chiasma frequency than males (see table 1), differences in chiasma distribution between sexes exist although they could be overestimated due to differences in cell and spindle size showed by male and female meiocytes.

The widespread existence of sex differences in chiasma frequency and distribution leads to a more fundamental question, that is whether such differences are indicative of separate meiotic controls in the two sexes or, on the contrary, they represent the response of a joint control to differing conditions in each sex (see Davies and Jones, 1974). This topic is at present under investigation.

Acknowledgement This work was partially supported by a grant of Universidad Complutense (UCP 01687).

\section{REFERENCES}

BENNETT, M. D., FINCH, R. A., SMITH, J. B. AND RAO, M. K (1973) The time and duration of female meiosis in rye, wheat and barley. Proceedings of the Royal Society, London B. $183,301-319$

BENNETT, J. H., HAYMAN, D. L. AND HOPE, R. M. (1986) Novel sex differences in linkage values and meiotic chromosome behaviour in a marsupial. Nature, 323, 59-60.

CALLAN, H. G. AND PERRY, P. E. (1977) Recombination in male and female meiocytes contrasted. Phil. Trans. Roy. Soc. London Series B, 277, 227-233.

CANO, M. I., JONES, G. H. AND SANTOS, J. L. (1987) Sex differences in chiasma frequency and distribution in natural populations of Eyprepocnemis plorans containing B chromosomes. Herediy, 59, 237-243.

CANO, M. I. AND SANTOS, J. L. (1988) B chromosomes of the grasshopper Heteracris littoralis: meiotic behaviour and endophenotypic effects in both sexes. Genome, 30, 797-801.

$\mathrm{CHURCH}, \mathrm{K}$. (1974) Meiosis in the grasshopper. III. Chiasma frequency in females after elevated temperature. Heredity, $32,159-164$

DAVIES, E. D. G. AND JONES, G. H. (1974) Chiasma variation and control in pollen mother cells and embryo-sac mother cells of rye. Genet. Res., 23, 185-190.

DUNN, L. C. AND BENNETT, D. (1967) Sex differences in recombination of linked genes in animals. Genet. Res., 9, 211-220.

FLETCHER, H. L. AND HEWITT, G. M. (1980) A comparison of chiasma frequency and distribution between sexes in three species of grasshoppers. Chromosoma, 77, 129-144.

FOGWILL, M. (1958) Differences in crossing-over and chromosome size in the sex cells of Lilium and Fritillaria. Chromosoma, 2, 493-504.

GOHIL, R. N. AND KAUL, R. (1980) Studies on males and females meiosis in Indian Allium I Four diploid species. Chromosoma, 77, 123-127.

HALDANE, J. B. S. (1922) Sex ratio and unisexual sterility in hybrid animal. $J$. Genet., 12, 101-109.

HENRIQUES-GIL, N. JONES, G. H., CANO, M. I., ARANA, P. AND SANTOS, J. L. (1986) Female meiosis during oocyte maturation in Eyprepocnemis plorans (Othoptera, Acrididae). Can. J. Genet. Cytol., 28, 84-87.

HEWITT, G. M. (1976) Meiotic drive for B-chromosomes in the primary oocytes of Myrmeleotettix maculatus (Orthoptera: Acrididae). Chromosoma, 56, 381-391. 
HEWITT, G. M. AND JOHN, B. (1965) The influence of numerical and structural chromosome mutations on chiasma conditions. Heredity, 20, 123-135.

JONES, G. H., STAMFORD, W. K. AND PERRY, P. E. (1975) Male and female meiosis in grasshoppers II Chorthippus brunneus. Chromosoma, 51, 381-389.

PARKER, J. S. (1975) Chromosome-specific control of chiasma formation. Chromosoma, 49, 391-406.

PASTOR, J. B. AND CALLAN, H. G. (1952) Chiasma formation in spermatocytes and oocytes of the turbellarian Dendrocoelum lacteum. J. Genet., 50, 449-454.

PERRY, P. E. AND JONES, G. H. (1974) Male and female meiosis in grasshoppers I Stethophyma grossum. Chromosoma, 47, 227-236.

RHOADES, M. M. (1978) Genetic effects of heterochromatin in maize. In Waiden, D. B. (ed.) Maize Breeding and Genetics, pp. 641-671.

SANTOS, J. L., CIPRES, G. AND LACADENA, J. R. (1989). A quantitative study of chiasma terminalization in the grasshopper Chorthippus jucundus, Heredity, 62, 51-57.
SOUTHERN, D. I. (1967) Chiasma distribution in truxaline grasshoppers. Chromosoma, 22, 164-191.

SPEED, R. M. (1977) The effects of ageing on the meiotic chromosomes of male and female mice. Chromosoma, 64, 241-254.

TEASE, C. AND JONES, G. H. (1976) Chromosome specific control of chiasma formation in Crepis capillaris. Chromosoma, $57,33-49$.

vosA, C. G. (1972) Two track heredity: differentiation of male and female meiosis in Tulbaghia Caryologia, 25, 275-281.

WATSON, I. D. AND CALLAN, H. G. (1963) The form of bivalent chromosomes in newt oocytes at first metaphase of meiosis. Quart. J. Microsc. Sci., 104, 281-295.

white, M. J. D. (1973) Animal Cytology and Evolution, 3rd ed. Cambridge University Press, London. 